Journal of Epidemiology and Public Health (2017), 2(1): 20-31

https://doi.org/10.26911/jepublichealth.2017.02.01.03

\title{
Effect of Locus of Control, Self-Efficacy, and Personality Type on the Quality of Life among Caregivers of Schizophrenia Patient in Godean Sub-District, Yogyakarta
}

\author{
Mulyanti'), Rita Benya Adriani 2), Setyo Sri Rahardjo 3) \\ 1) Masters Program in Public Health, Sebelas Maret University \\ 2) Health Politechnics Program Surakarta \\ 3) Faculty of Medicine, Sebelas Maret University
}

\begin{abstract}
Background: Caregivers of schizophrenia patients have an important role in fulfilling the need of patients. This task implicates on care burden and psychological problems on the caregivers. The quality of life of the caregivers may have important impact on the caring process. This study aimed to examine effect of locus of control, self-efficacy and personality type on the quality of life among caregivers of schizophrenia patient.

Subjects and Method: This study was analytic observational with cross-sectional design. It was carried out at Godean Sub-District, Yogyakarta, from March to April 2017. A sample of 102 caregivers of schizophrenia patient were selected for this study by fixed diseases sampling. The dependent variable was quality of life. The independent variables were age, gender, personality type, locus of control, self-efficacy, family concern, family income. The data was collected by questionnaire, and analyzed by path analysis.

Results: Higher quality of life of caregivers was affected by self-efficacy $(b=0.46 ; S E=0.15$; $\mathrm{p}<0.001)$, extrovert personality $(b=0.21 ; \mathrm{SE}=0.10 ; \mathrm{p}=0.01)$, and higher family income $(\mathrm{b}=0.18$; $\mathrm{SE}=0.05 ; \mathrm{p}=0.02)$. Self-efficacy was affected by better family concern $(\mathrm{b}=0.22, \mathrm{SE}=0.16$; $\mathrm{p}=0.02)$ and extrovert personality $(\mathrm{b}=0.33 ; \mathrm{SE}=0.06 ; \mathrm{p}<0.001)$.

Conclusion: Higher quality of life of caregivers was directly affected by self-efficacy, extrovert personality, and higher family income. Higher quality of life of caregivers was indirectly affected by better family concern and extrovert personality.
\end{abstract}

Keywords: quality of life, locus of control, self-efficacy, schizophrenia, caregiver

\section{Correspondence:}

Mulyanti. Masters Program in Public Health, Sebelas Maret University, Surakarta. Email: kalilaputri2811@gmail.com. Mobile: +6285868823105.

\begin{tabular}{l}
\hline BACKGROUND \\
Mental disorder is one of serious health \\
problems faced by every country including \\
Indonesia. Schizophrenia is a chronic \\
mental disorder that affects way of \\
thinking, behavior and it is marked by the \\
occurrence of obvious psychotic symp- \\
toms such as hallucination, agitation, \\
insomnia and others. The disease takes a \\
long process and it affects the entire \\
aspects of patients' life. Therefore schizo- \\
phrenia becomes one of the diseases that \\
contribute on global disease burden
\end{tabular}

(Fischer dan Buchanan, 2016). Schizophrenia is one of the main causes of disability. It is because of the occurrence of setbacks on physical health that probably is accompanied by complication, cognitive function decline, deficit on the psychomotor performance/ skills, and reducing level of independence (Strassing et al., 2014). As the consequence schizophrenia patients are not able to perform daily activities well so that they need other people to take care of them (caregiver) (Prianto, 2005 in Fitrikasari et al., 2012). 
Family is the primary caregiver that has an important role to help patients' recovery. A caregiver of schizophrenia patients possesses care burden that can concern his psychological well being and at risk for mental disorder (Geriani et al., 2015; Gupta et al., 2014; Lesibikan and Ayinde, 2013). The burden a caregiver undergoes may lead to the low quality of life that can affect the process of care and the accomplishment of treatment on schizophrenia patients (Geriani et al., 2015). Quality of life of the caregivers is a key of success in giving treatment (Margetic et al., 2013).

Quality of life of a caregiver of schizo-phrenia patients is affected by negative stigma from society, level of education (social and environmental aspect), health condition of caregiver, level of depression (physical and psychological aspects), and the duration of disease (El-Tantawi et al., 2010; ZamZam et al., 2011). Quality of life is also affected by self efficacy (Cramm et al., 2012; Testa et al., 2016). High level of efficacy on a caregiver of schizophrenia patients affects on the level of life contentment, the low acceptance of care burden, and better quality of life (Lakhani and Shardha, 2016).

One's self efficacy is affected by the occurrence of force from within (internal) and outside (external) that is commonly known as locus of control/perception toward control. The locus of control is related to self efficacy, self concept, and self esteem that can influence one's view toward his behavior (Bandura, 1977 in Gerald, 2016). Someone with high locus of control and self efficacy have good capacity to control his life (Kauba and Pitlik, 2014).

Number of schizophrenia patients in the world is still relatively high. It is esti- mated there are 21 million of people who suffer from schizophrenia (WHO, 2016). Based on Indonesia Basic Health Resarch (Riskesdas) year of 2013 the number of Psychotic Mental Disorder in Indonesia was 1.7 per mill and Special Region of Yogyakarta was in the top rank that was 2.7 per mill ( 9,820 people), whereas the number of mental disorder in Sleman Regency was 1.52 per mill (1,769 people) (Balitbang Kemenkes RI, 2013).

Godean Sub-district is one of the sub districts in Sleman Regency. There were still few activities intended for caregivers. In addition, health problems faced by caregivers were not yet completely detected. The purpose of the study was to analyze factors that affect life quality of caregivers of schizophrenia patients in Godean Sub-district, Special Region of Yogyakarta.

\section{SUBJECTS AND METHOD \\ 1. Design of the Study \\ The study was a quantitative study. The design of the study was observational with cross sectional approach. The study was conducted in Godean sub-district, Special Region of Yogyakarta in the months of March and April 2017.}

\section{Population and Sampling}

The population of the study was all caregivers of schizophrenia patients in Godean Sub-district, Special Region of Yogyakrta. There were a total of 102 selected as the subjects of the study, who was selected by using fixed disease sampling. Subject selection was based on status of the disease, consisted of those who suffered from the disease or who did not suffer from the disease being studied, whereas status of subjects' exposure were varied in accordance with the status of subjects' disease (Murti, 2013). 
Journal of Epidemiology and Public Health (2017), 2(1): 20-31

https://doi.org/10.26911/jepublichealth.2017.02.01.03

Inclusion criteria among others were: caregivers were between $18-60$ years of age, took care of schizophrenia patients based on doctors' diagnosis, performed care for outpatients, performed care without any rewards and had been performing care for at least 1 year.

\section{Variables of the study}

There were eight variables in the study, consisted of dependent and independent variables. The dependent variable was quality of life of caregivers of schizophrenia patients. The independent variables were age, sex types, income, personality types, concern/ caring, self efficacy, locus of control.

\section{Operational Definitions}

Age of the study subjects was defined as age which was calculated from birth until the implementation of the study and stated in year; sex categories of the study subjects was defined as physical identification based on the differences in anatomy and physiology structure on human; income of the study subjects was defined as the source of income received by caregivers of schizophrenia patients and used to fulfill his/her needs and desires.

Types of personality was pattern of thinking, differences in characteristic patterns of thinking, feeling and behaving of caregivers of schizophrenia patients. Family concern/ caring was defined as the family's feeling of concern toward caregivers of schizophrenia patients by showing attention, empathy and compassion in giving treatment for patients.

Locus of control was a belief/ encouragement that came from either internal or external of an individual that influences caregivers in taking care of schizophrenia patients. Self efficacy was a confidence possessed by caregivers in taking care of schizophrenia patients; quality of life of caregivers of schizophrenia patients was how a caregiver of schizophrenia patient valued the positive aspects within her/himself included physical, mental, social and environmental.

\section{Instrument variable}

Data collection was conducted by using questionnaires. The standard questionnaires used were among others general self efficacy, locus of control, WHOQOL$B R E F$. Meanwhile questionnaires on personality types and family concern were made by the researcher therefore it needed to conduct validity and reliability tests.

Based on the result of reliability test on item-total correlation, it was found that the measurement of family concern and personality types was $r$ count $\geq 0.20$, and Cronbach's Alpha $\geq 0.70$, therefore each question item were declared as reliable.

\section{Data analysis}

Characteristics of sample data were continually described in $\mathrm{n}$, mean, SD, minimum, maximum. Categorical sample data was described in $\mathrm{n}$ and percentage. Bivariate analysis on continuous data used Pearson correlation, whereas multivariate analysis was analyzed by using path analysis model. Steps of data analysis by using path analysis, among others:

1. Model specification

2. Model Identification

3. Model Compatibility

4. Parameter estimation

5. Model respecification 
The result of descriptive statistics on continuous data namely family concern, personality types, locus of control, self Table 1. Characteristics of study subjects

\begin{tabular}{lllc}
\hline Characteristics & \multicolumn{1}{c}{ Criteria } & n & \% \\
\hline Age & 18-45 year & 21 & 20.6 \\
& 46-60 year & 81 & 79.4 \\
Sex categories & Male & 36 & $35 \cdot 3$ \\
& Female & 66 & 64.7 \\
Income & <Regional & 28 & 27.5 \\
& Minimum Wage & & 72.5 \\
& 2Regional & 74 & \\
& Minimum Wage & & \\
\hline
\end{tabular}

Table 2. Univariate analysis on variables of the study

\begin{tabular}{lccccc}
\hline Variables & n & Mean & SD & Min & Max \\
\hline Family Concern & 102 & 9.6 & 2.98 & 2 & 13 \\
Caregivers' type of personality & 102 & 50.4 & 7.96 & 23 & 65 \\
Caregivers' locus of control & 102 & 9.78 & 2.74 & 3 & 15 \\
Caregivers' self efficacy & 102 & 31.9 & 5.22 & 14 & 40 \\
Caregivers' quality of life & 102 & 67.12 & 9.44 & 37.5 & 81.25 \\
\hline
\end{tabular}

Table 2 showed that each variable had relatively small data variety. Mean represented the average value, standard deviation (SD) represented how great the efficacy, and quality of life can be seen in Table 2. data would varied. The small SD was an indication that the data was representative.

Table 3. Bivariate analysis on the effect of age, sex categories, family concern, type of personality, income, locus of control, self efficacy toward the quality of life of caregivers of schizophrenia patients

\begin{tabular}{lcc}
\hline \multicolumn{1}{c}{ Independent Variables } & r & p \\
\hline Age & 0.98 & -0.003 \\
Sex categories & 0.89 & 0.014 \\
Family concern & 0.27 & 0.006 \\
Type of personality & 0.37 & 0.000 \\
Income & 0.08 & 0.410 \\
Locus of control & 0.08 & 0.073 \\
Self efficacy & 0.55 & 0.000 \\
\hline
\end{tabular}

Table 3 showed that good family concern ( $\mathrm{r}=0.27 ; \mathrm{p}=0.006)$, type of personality $(\mathrm{r}=0.37 ; \mathrm{p}=0.000)$, self efficacy $(\mathrm{r}=0.55$; $\mathrm{p}<0.001)$ had positive effects toward the quality of life of schizophrenia patients and statistically significant.

Path analysis model made by the researcher was based on the theory later, the compatibility was checked by using good correlation model according to SPSS that was known as saturation model.

Picture 1 showed the structural model after an estimation. Indicator that showed model compatibility on path analysis was represented by the occurrence of goodness of fit measure (measurement of model compatibility), it obtained CMINfit index as big as 4.07; $\mathrm{p}=0.40>0.05$; NFI= $0.96 \geq 0.90$; $\mathrm{CFI}=0.99 \geq 0.95$; RMSEA= $0.01 \leq 0.08$, it means the model fit the criteria that were determined and stated by using empirical data. 


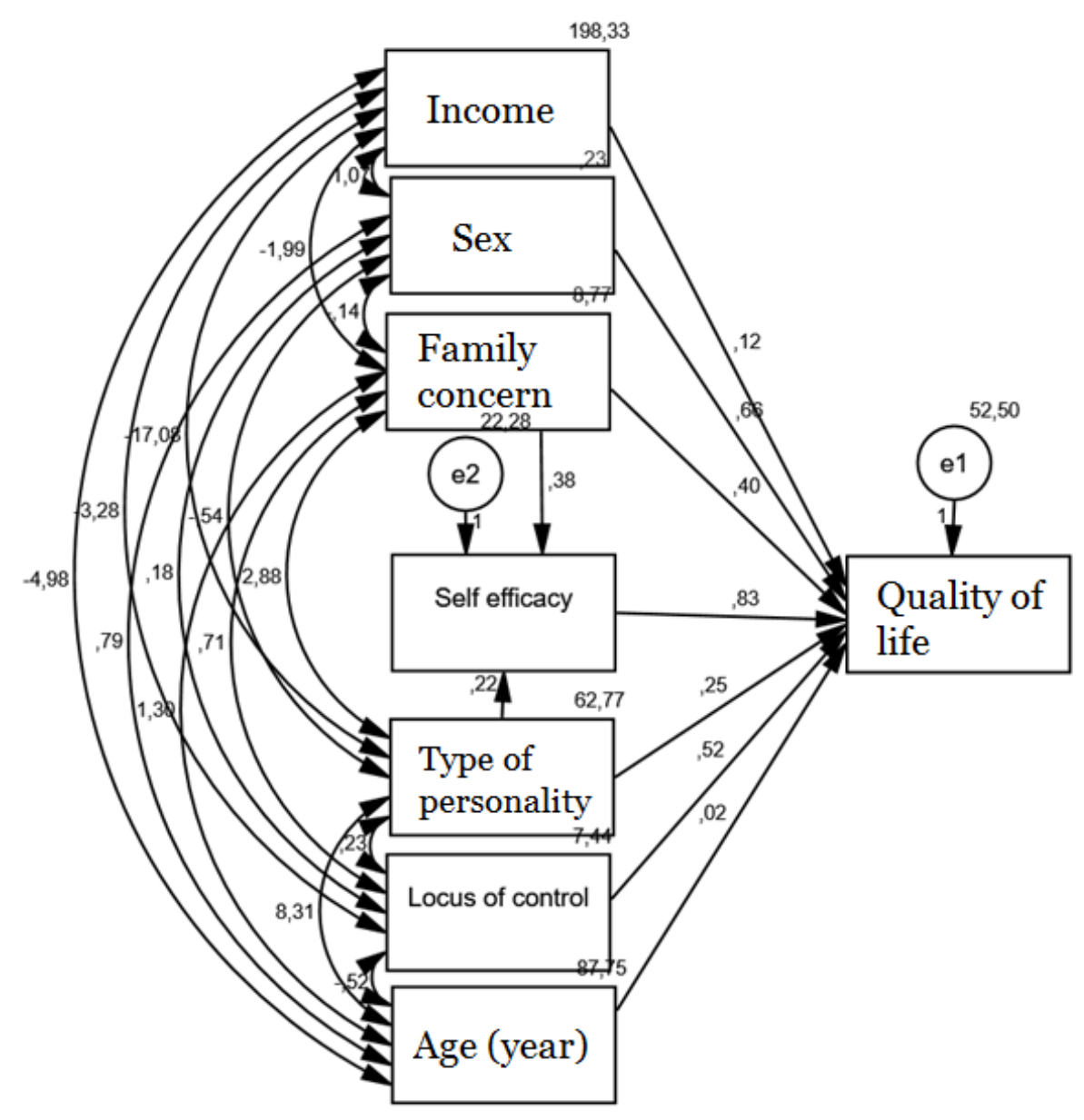

Picture 1. Structural Model on Path Analysis

Table 4. Result of Path Analysis

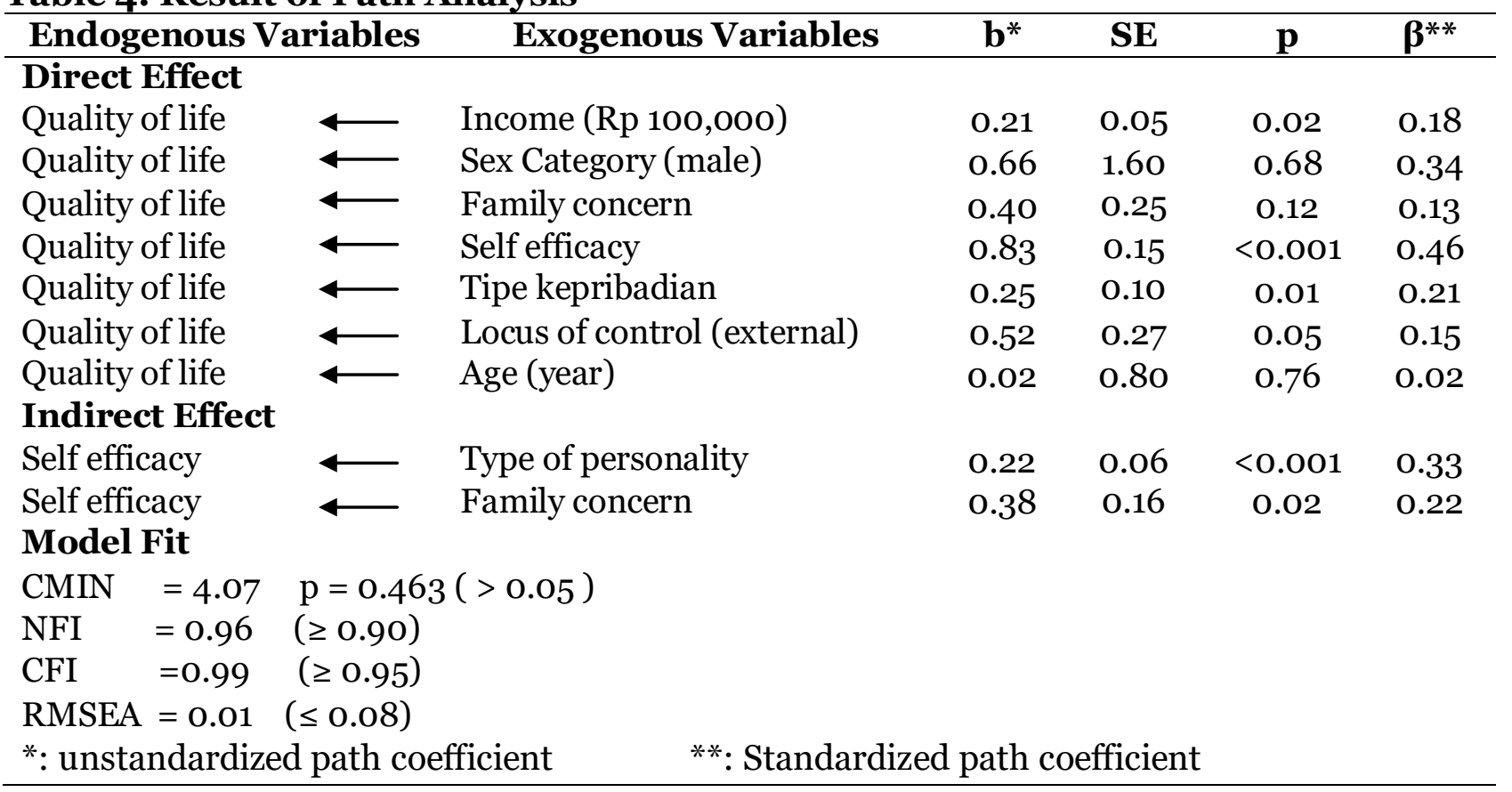


It was identified from Table 4 that quality of life of caregivers of Schizophrenia patients was directly affected by income, self efficacy and type of personality. Each increasing unit of income would increase the quality of life of caregivers by 0.21 unit $(b=0.21 ; \mathrm{SE}=0.05$; $\mathrm{p}=0.02)$.

Each increasing unit of extrovert personality type would increase the quality of life by 0.25 unit $(b=0.25$, $\mathrm{SE}=0.10 ; \mathrm{p}=0.01)$. Each increasing unit of self efficacy would increase the quality of life by $0.83(b=0.83 ; \mathrm{SE}=0.15 ; \mathrm{p}<0.001)$. Each increasing unit of type of personality (extrovert) would increase self efficacy by 0.022. $(b=0.22 ; S E=0.16 ; p=0.02)$. Every increasing unit of self efficacy would increase self efficacy by $0.38 \quad(b=0.38$; $\mathrm{SE}=0.16 ; \mathrm{p}=0.02)$.

\section{DISCUSSION}

1. The effect of income toward quality of life of caregivers of schizophrenia patients

There was a positive correlation between income and the quality of life of caregivers of schizophrenia patients. Caregivers whose high income increases the possibility for good quality of likfe. According to National for National Statistics (2015) income/ wealth will influence one's welfare.

Low income will influence one's vitality and health (Costa et al., 2013). With adequate income someone will obtain healthcare service more easily, therefore it will influence his quality of life. According to $\mathrm{Yu}$ et al., (2013) income does not influence one's quality of life. Underprivileged community still obtain healthcare service for free since they were supported by health insurance aid from the government.
Schizophrenia is a chronic mental disorder therefore it needs assistance in fulfilling his needs. It brings care burden such as in economy, social, psychology, and others (Sigh and Prajawati, 2012). Financial burden is one of the factors that influence the low quality of life of caregivers. Caregivers should stop working or reduce their savings for treatment and medication (Nayak et al., 2014).

Income of caregivers of Schizophrenia patients affects their quality of life. It is in accordance with this study that showed the significant correlation between income and the quality of life of caregivers of schizophrenia patients. Schizophrenia patients need fund for their regular treatment however some of them have possessed health insurance to get healthcare service for free, therefore the quality of life of their caregivers is still maintained despite the small income.

\section{The effect of sex categories toward the quality of life of care- givers of schizophrenia patients}

Based on the statistics test, it showed that there was no correlation between sex categories with the quality of life of caregivers. The result is in accordance with the stidy made by Jain and Sigh (2014) and Kaur (2014) that there is no significant correlation between sex categories with quality of life. Quality of life of male and female is more correlated to level of stress and psychological condition (Vanagas dan Axelsson, 2004).

Quality of life of men is more affected by economy, physical, and psychological condition, whereas on women, it is affected by physical and psychological health (Campos et al, 2014). Women are more likely to get stressed compare to men therefore it affects their quality of life (Gottlieb et al., 2014). 
Journal of Epidemiology and Public Health (2017), 2(1): 20-31

https://doi.org/10.26911/jepublichealth.2017.02.01.03

There are several differences of study result related to the correlation between sex categories and quality of life. They are only able to define the correlation in one group respectively. The inconsistency shows that there is no a definite explanation about the correlation between sex categories and quality of life.

Life burden undergone by the caregivers of schizophrenia patients is affected by age, sex categories, level of education and others (Shamsaei et al., 2015). The result of the study is in contradiction with several previous studies. Sex categories does not correlate with the quality of life of caregivers since there were some matters found during the process of study, among others were the condition of patients being taken care of was well maintained, regularly obtained treatment, and were always supported by their family.

\section{The correlation between age and quality of life of caregivers of schizo- phrenia patients}

There was no significant correlation between age and quality of life of caregivers of schizophrenia patients. It is in contradiction with the opinion from Xie et al., (2016) the age of caregivers significantly affect the quality of life on physical aspect. It is more related to one's physical function declining along with the age therefore it affects the process of treatment.

Quality of life within a family is affected by kinship system (Margetic et al., 2013). The older the person it will affect the quality of copping strategy toward a problem (Cramm et al., 2012). The result of the study is in contradiction with the previous study that shows age and sex categories do not have significant correlation. It is because of the shifting of treatment from hospital into community, therefore family (parents, siblings, children) is demanded to be able to take care of schizophrenia patients. Caregivers of schizophrenia patients have the similar care burden despite of different age that can affect their quality of life, besides caregivers always obtain excellent family support. It affects the quality of life of the caregivers.

\section{The correlation between type of personality with quality of life of caregivers of schizophrenia patients}

There was a positive correlation between extrovert personality type with quality of life of caregivers of schizophrenia patients and statistically significant. Type of personality affects care burden that gives impact to mental health of caregivers such as neurotic disorder (Abraldes et al., 2013). Symptoms of neurosis, level of depression, and care burden are reducing on caregivers whose personality type is extrovert (Melo et al., 2010).

Extrovert personality negatively related to quality of life (Hossein-khanzadeh and Taher, 2013). Extrovert personality compares to introvert personality. The result of the study showed there was a correlation between extrovert personality type with quality of life of caregivers of schizophrenia patients. Caregivers with extrovert personality are likely to be open to other people, therefore the level of depression and care burden o caregivers of schizophrenia will be reducing. Caregivers with low level of depression and care burden will lead to better quality of life (Settineri et al., 2014).

5. The correlation between self efficacy and quality of life of caregivers of schizophrenia patients

There was a positive correlation between self efficacy with quality of life of caregiver of schizophrenia patients and statistically 
significant. Cancer patients with high self efficacy have high quality of life (Liang et al., 2015). Cramm et al., (2013) explains that adolescents with Diabetes Mellitus are likely to have high life confidence, however their quality of life tend to be getting declining. The disease that is suffered by those teenagers affects their quality of life.

Caregivers of schizophrenia with high self efficacy increase life contentment and reduce care burden (Lakhani dan Shradha, 2016). Improving self efficacy helps someone to improve his quality of life (Haugland et al., 2016).

Caregivers' self confidence on his capacity in giving treatment is the primary key in helping patients to recover. Self confidence is able to improve caregiver's concern to patients therefore it promotes the recovery. Patients' well being promotes the improvement of caregivers' quality of life (Crellin et al., 2014).

\section{The correlation between locus of} control and quality of life of caregivers of schizophrenia patients

Locus of control and quality of life of caregivers do not statistically correlate. The result is in contradiction with several results of studies that explain the occurrence of correlation between locus of control with life quality (Heidari dan Ghodusi, 2016; Aliha, 2015). People with external locus of control are likely to suffer from psychological disorder such as depression compare to people with internal locus of control. Result of the study shows that internal locus of control and extrovert personality improve quality of life (Kandi and Zeinali, 2016).

Maximum level of contentment occurs when internal and external locus of control are in balanced which is commonly known as biolocal expectancy. Either internal or external locus of control only represents one imbalanced locus, therefore contentment will not be optimal (April et al., 2017).

There are several previous study results that are not in accordance with the result of the study. The difference is caused by the occurrence of other factors that affect the quality of life a caregivers such as level of depression, self esteem, care burden and others.

7. The correlation between family concern, self efficacy and quality of life of caregivers of schizophrenia patients

Family concern through self efficacy affects the quality of life. Excellent family support is able to improve self confidence. Family is the first and primary environment that influences someone (Widanarti dan Indati, 2002).

Caregivers need the availability of health information, support to obtain aids from the professionals and support from the community including family support. Care burdens which are experienced the most by caregivers are financial and time burden (Kumar et al., 2015). Most of caregivers feel contented with the relationship and social support they received. Financial burden and treatment time are related to social support. Good social support will improve the quality of life a caregivers (Anjas et al., 2015).

Social support and self efficacy for caregivers are able to minimize the existing stressors so that caregivers as well as family become more resilient in facing problems (Weiss et al., 2013). Self efficacy contributes as a variable between social support and copping mechanism that help minimizing depression incidents on caregivers. Caregivers who obtain excellent family and social support are able to improve self efficacy therefore able to minimize psychological problems such 
Journal of Epidemiology and Public Health (2017), 2(1): 20-31

https://doi.org/10.26911/jepublichealth.2017.02.01.03

as depression and it affects their quality of life (Tang et al., 2015), (Deakhashanpur et al., 2015).

\section{The correlation between types of personality, self efficacy and quality of life of caregivers of schizophrenia patients}

There was a positive correlation between extrovert personality type with self efficacy od caregiver of schizophrenia patients and statistically significant. According to Pandey and Kavita (2015) there is significant correlation between extrovert personality type, openness to experiences, with self efficacy.

Personality types through self efficacy affect one's welfare (life satisfaction and subjective happiness) (Strobel et al., 2013). A mother with extrovert personality and is emotionally stable will have high self confidence so that she is able to breastfeed for a longer period of time. Extrovert personality encourages an individual to look for supports therefore his self confidence is increasing and it gives impact to the improvement of quality of life (Brown, 2013).

Caregivers of schizophrenia patients whose personality is extrovert tend to try to find support for helping patients' recovery. The support obtained by caregivers will increase their self confidence in giving treatment to patients therefore it can reduce care burden that generates the improvement on their quality of life. An individual with extrovert personality is usually more open to the experience he encounters.

Based on the result of the study, it can be concluded that the quality of life of caregivers of schizophrenia patients is affected by income, self efficacy, and type of personality (extrovert). Self efficacy is affected by type of personality (extrovert) and high family concern.

\begin{tabular}{l}
\hline REFERENCE \\
\hline Abraldes IG, José CMC, Calenti JCM, \\
López LL, Maseda A (2013). The \\
Influence of Neurocism and \\
Extraversion on the Perceived \\
Burden of Dementia Caregivers: an \\
Exploratory study. Gerontology and \\
Geriatrics, 56 (2013): 91-95. \\
Aliha JK (2015). Relationship of Assess \\
Self-Esteem and Locus of Control \\
with Quality Of Life During Treat- \\
ment Stages in Patients Referring to \\
Drug Addiction Rehabilitation Cen- \\
ters. Client-Centered Nursing Care, \\
1(2): 83-89.
\end{tabular}

Anjos KFD, Boery RNSO, Pereira R, Larissa CP, Pedreira LC, Vilela ABA, Santos VC, Rosa DOS. (2015). Association between Social Support and Quality of Life of Relative Caregivers of Elderly Dependents. Ciência \& Saúde Coletiva, 20(5):1321-1330.

April KA, Dharani B, Peters K (2012). Impact of Locus of Control Expectancy on Level of Well-Being. Review of European Studies, 4(2). https://www.ashridge.org.uk/MediaLibrary/Ashridge/PDFs/Publications/Impac tOfLocusOfControlExpectancy.pdf. diakses 1 Januari 2017.

Brown A (2013). Maternal Trait Personality and Breastfreeding duration: the importance of confidence and social support. Journal of Advanced Nursing. 7: 587-598.

Campos ACV, Ferreira EF, Vargas AMD \& Albana C (2014). Aging, Gender and Quality of Life (AGEQOL) Study: Factors Associated with Good Quality Of Life in Older Brazilian 
Community-Dwelling Adults. Biomed Central, 12 (166).

Costa TF, Costa KNFM, Fernandes MGM, Martins KP, Brito SS (2014). Quality of Life of Caregivers for Patients of Cerebrovaskuler Acciddents: Association of (Socio-Demographic) Characteristics and Burden. Revista Da Escola De Enfermagem Da Usp, 49(2): 243-250.

Cramm JM, Strating MMH, Nieboer AP (2012). Satisfaction with Care as a Quality-of-Life Predictor for Stroke Patients and Their Caregivers. Quality of Life Research. 21(10): 1719-1725.

Crellin NE, Orrell M, McDermott O, Charlesworth G (2014). Self Efficacy and Health related Quality of Life in Family Carers of People with Dementia: a systematic review. 2014. Aging and Mental Health, 8(18): 954-969.

Derakhshanpour F, Vakili MA, Farsinia M, Mirkarimi K (2015). Depression and Quality of Life in Patients With Type 2 Diabetes. Iranian Red Crescent Medical Journal, 17(5).

El-Tantawi AMA, Yasser MR, Al-Sayed MKZ (2010). Depressive Disorders Among Caregivers of Schizophrenia Patients in Relation to Burden of Care and Perceived Stigma. Current Psychiatry, 17(3).

Fischer BA, Buchanan RW (2016). Schizophrenia: Epidemiology and pathogenesis. Dalam http://www.uptodate.com/contents/schizophreniaepidemiology-and-pathogenesis.

Diakses 23 Oktober 2016.

Fitrikasari A, Kadarman A, Sarjana W (2012). Gambaran Beban Caregiver Penderita Skizofrenia di Poliklinik Rawat Jalan RSJ Amino Gondo- hutomo Semarang. Medica Hospitalia, 1(2): 118-122.

Gerald CA (2015). Enhancing Quality of Life: The Effects of Positive Cognitions. Walden Dissertations and Doctoral Studies. Dalam http://scholarworks.waldenu.edu/dissertat ions. diakses pada tanggal 30 Desember 2016.

Geriani D, Savithry KSB, Shivakumar S, \& Kanchan T (2015). Burden of Care on Caregivers of Schizophrenia Patients: A Correlation to Personality and Coping. Journal of Clinical and Diagnostic Research: JCDR, 9(3): 01-04.

Gottlieb SS, Khatta M, Friedmann E, Einbinder L, Katzen S, Baker B, Marshall J, Minshall S (2014). The Influence of Age, Gender, and Race on the Prevalence of Depression in Heart Failure Patients. Journal of the American College of Cardiology, 9(43).

Gupta A, Solanki RK, Koolwal GD \& Gehlot S (2014). Psychological WellBeing and Buden in Caregivers of Patients with Schizophrenia. International Journal of Medical Science and Public Health, 4: 70-76.

Haugland T, Wahl AK, Hofoss D, DeVon HA (2016). Association between General Self-Efficacy Social Support, Cancer-related Stress and Physical Health-related Quality of Life : a Path Model Study in Patients with Neuroendocrine Tumors. Bio Medical Central, 4(11).

Heidari M, Ghodusi M (2016). Relationship of Assess Self-Esteem and Locus Of Control with Quality of Life during Treatment Stages in Patients Referring to Drug Addiction Rehabilitation Centers. Materia SocioMedica, 28 (4): 263-267. 
Journal of Epidemiology and Public Health (2017), 2(1): 20-31

https://doi.org/10.26911/jepublichealth.2017.02.01.03

Hosseinkhanzadeh AA dan Taher M (2013). The Relationship between Personality Traits with Life Satisfaction. Sociology Mind, 1(3): 99-105.

Jain A, Sigh DC (2014). Resillience and Quality of life in Caregivers of Schizophrenia and Bipolar Disorder Patients. Global Journal of HumanScience a Art and HumanitiesPsychology, 14(5).

Kandi NAH, Zeinali A (2016). Relationship between Personality Characteristics, Internal Locus of Control, Psycho-logical Hardiness and Nurses Quality of Life. Journal of Research Development in Nursing \& Midwifery, 2(13): 8-15.

Kauba L, Pitlik H (2014). I wanna life my life : Locus of Control and Support for the Welfare State. MENDELU Working Papers in Business and Economics 46/2014. Mendel University in Brno. Cited from: http://ideas.repec.org/s/men/wpaper.html.

Kaur N (2014). Caregiving Burden and Social Support among caregiver of schicophrenia patients. Delhi Psychiatry Journal, 17(2).

Kumar R, Kaur S, Reddemma K (2015). Needs, Burden, Coping and Quality of Life in Stroke Caregivers A Pilot Survey. Nursing and Midwifery Research Journal, 2(11): 57-67.

Lakhani MSA, Sakatkar SR (2016). Correlational Study of Life Satisfation, Caregiving Self-Efficacy and Burden of Caregiving in the Primary Caregivers of Chronic Schizophrenia Patients in Pune. The International Journal of Indian Psychology, 3: 138-144.

Lasebikan VO, Ayinde OO (2013). Family Burden in Caregivers of Schizophrenia Patients: Prevalence and Socio- demographic Correlates. Indian Journal of Psychological Medicine, 35(1): 60-66.

Liang SY, Ding SA, Wu WW, Liu CY, Lin CC (2015). Opiod Taking Self Efficacy Affects The Quality of Life of Taiwanese Patients with Cancer Pain. Supportive Care in Cancer, 23 : 2113-2120.

Margetić BA, Jakovljević M, Furjan, Margetić B3, Marsanić VB (2013). Quality of Life of Key Caregivers of Schizophrenia Patients and Association with Kinship. Center European Journal of Public Health, 21(4): 220223.

Melo G, Maroco J, de Mendonça A. (2011). Influence of Personality on Caregiver's Burden, Depression and Distress related to the BPSD. International Journal of Geriatric Psychiatry, 26(12): 1275-82.

Murti B (2013). Desain dan Ukuran Sampel untuk Peneltian Kuantitatif dan Kualitatif di Bidang Kesehatan. Yogyakarta: Gajah Mada University Press.

Nayak MG, George A, Vidyasagar MS, Kamath A (2014). Quality of Life of Family Caregivers of Patients with Advanced Cancer. Journal of Nursing and Health Science, 3: 7075 .

Office for National Statistics (2015). Relationship between Wealth, Income and Personal Well Being, July 2011 to June 2012. Dalam http://webarchive.Nationalarchives.gov.uk/20160105160709/http://www.ons.gov.uk/ons/dcp171776_415633.pdf. Diakses pada tanggal 21 Mei 2017.

Pandey NS, Kavitna M (2015). Relationship between Teacher's Personality and Self Efficacy: An Empirical Analysis of School Teacher in 
Karaikal Region (Puducherry). Public Business Revies International, 3: 37-41.

Settineri S, Rizzo A, Liotta M, Mento C (2014). Caregiver's Burden and Quality of Life: Caring for Physical and Mental Ilness. International Journal Phychology Research, 7(1): 30-39.

Shamsaei F, Cheraghi F, Bashirian S. (2015). Burden on Family Caregivers Caring for Patients with Schizophrenia. Iranian Journal of Psychiatry, 10(4):239-245.

Sigh PM, Prajapati A (2012). Burden of Schzophrenia on Caregivers in Nepal. Nepal Medical College Journal, 15(2): 140-143.

Strassing M, Signorile J, Gonzales C, Harvey PD (2014). Physical Performance and Disability in Schizophrenia. National Institute of Health Public Access, 1(2): 112-121.

Strobel M, Tumasjan A, Spörrle M (2011). Be Yourself, Believe in Yourself, and be Happy: Self Efficacy as a Mediator between Personality Factors and Subjective Well-Being. Scandinavian Journal of Psychology, (52): $43-48$.

Tang F, Jang H, Lingler J, Tamres LK, Erlen JA (2015). Stressors and Caregivers' Depression: Multiple Mediators of Self-Efficacy, Social Support, and Problem-solving Skill. Social work in Health Care. 54(7):651-668.

Testa S, Molinengo G, Oggero A, Rosato R. (2016). The Relationship Between Self-Efficacy and Health-Related Quality of Life in Multiple Sclerosis Patients. http://ubplj.org/index.- php/ejpch/article/view/970. diakses pada tanggal 30 Desember 2016.

Vanagas G, Axelsson SB (2004). Do Gender Difference Have Influence on Psychosocial Stress, Quality of Life and Work Demands? Cross Sectional Study. Europe Journal General Medicine, 1(4): 36-41.

Weiss JA, Robinson S, Fung S, Tint A, Chalmers P, Lunsky Y (2013). Family Hardiness, Social Support, and Self Efficacy in Mother of Individuals with Autism Spectrum Disorders. Research in Autism Spectrum Disorder, 7: 1310-1317.

Widanarti N, Indati A (2002). Hubungan antara Dukungan Sosial Keluarga dengan Self Efficacy pada Remaja di SMU Negeri 9 Yogyakarta. Jurnal Psikologi, 2:112-123.

Yu Y, Hu J, Efird JT, McCoy TP (2013). Social Support, Coping Strategies and Health related Quality of Life among Primary Caregivers of Stroke Survivo in China. Journal of Clinical Nursing, 22(15-16) 2160-2171.

ZamZam R, Midin M, Hooi LS, Yi EJ, Ahmad SNA, Azman SF, Borhanudin M, Radzi RSM (2011). Schizophrenia in Malaysian Families: A Study on Factors Associated with Quality of Life of Primary Family Caregivers. International Journal of Mental Health System, 5(16). 